\title{
Histopathological and microanalytical study of zirconium dioxide and barium sulphate in bone
} cement

\author{
C E Keen, G Philip, K Brady, J D Spencer, D A Levison
}

\begin{abstract}
Aims: To report the appearances of zirconium dioxide and barium sulphate in interface membranes, synovium, and other tissues around joint prostheses.

Methods: Histological sections from 23 specimens were reviewed by light microscopy and polarisation. Scanning electron microscopy and $x$ ray microanalysis were performed on routinely processed paraffin wax sections.

Results: Polyethylene, metals, and polymethylmethacrylate cement debris were easily recognisable. Almost all the cement remnants contained either zirconium dioxide or barium sulphate, confirmed by microanalysis. The contrast media had characteristic light microscopic appearances. Zirconium was identified in macrophages away from cement remnants. Conclusion: The presence of radiographic contrast media in tissues around prosthetic joints is common but not widely recognised.
\end{abstract}

(f Clin Pathol 1992;45:984-989)

Contrast media are added to polymethylmethacrylate cement used in joint replacement operations to confer radiopacity. The common media used are zirconium dioxide and barium sulphate. Although the acrylic cement is largely lost during routine processing, these contrast media can be identified in the resultant spaces in histological sections of synovium and other periarticular tissues excised during biopsy or revision of joint replacement. We could find no detailed accounts of the histological appearances of these media in such tissues. In a study of the reaction of bone to methacrylate Willert et al detected the presence of contrast media by electron microprobe studies and described the zirconium dioxide particles as "mulberryshaped".' Revell described the presence of contrast media as a useful indicator that tissue spaces were the site of bone cement. ${ }^{2}$ Meachim et $a l$, in experimental studies of synovial response to acrylic cement, used the presence of barium sulphate as a marker of the sites of acrylic cement dissolved in processing. ${ }^{3}$ A German publication documents histiocytic reaction and intracytoplasmic localisation of zirconium oxide and polymethylmethacrylate wear particles in interface membranes by transmission electron microscopy and laser microprobe mass analysis. ${ }^{4}$ The same group identified and graded wear debris, including zirconium in draining lymph nodes, in necropsy material. ${ }^{5}$ Another group discussed the effect of the contrast media on the tissue reaction in relation to joint protheses. ${ }^{6}$ Experiments have been reported showing that scratching damage to stainless steel femoral head components is predominantly caused by the abrasive effect of $x$ ray contrast media in acrylic cement. ${ }^{78}$ The scratched femoral head component then causes increased wear in the polyethylene acetabular cup.

We undertook a critical light, polarisation, and scanning electron microscopic review of 23 cases of cement or other wear particle deposition in relation to prosthetic joints, to search for these media and to characterise their appearances. The specificity of our findings was supported by microanalysis of paraffin wax sections by energy dispersive $x$ ray spectroscopy.

\section{Methods}

The 23 cases that form the basis of this study were collected from the referral files of one of the authors (DAL) and the surgical files of Guy's and Lewisham hospitals. The clinical details are shown in table 1 . The study was set up following the unexpected analytical finding of zirconium in four consecutive synovial biopsy specimens from patients with joint prostheses. We included all our samples (accrued over two years) of periarticular tissue containing foreign material from patients with a prosthetic joint or other implant.

Representative haematoxylin and eosin stained sections were examined by light microscopy and with polarised light.

Scanning electron microscopy (SEM) in conjunction with $x$ ray energy dispersive spectroscopic microanalysis (EDS) was performed in all cases. In brief, dewaxed sections (stained or serial unstained) were transferred from glass slides to a Perspex substrate using an organic based glue (Beecham UHU). The sections were carbon coated and inserted into the specimen chamber of an Hitachi S520 microscope equipped with an $\$ 4548$ high efficiency scintiliator type backscatter detector and a Kevex 4460 delta class analyser. Secondary electron images and backscattered electron images (providing atomic number related as well as topographic images) of the contrast media and wear particles were photographed. Numerous particles of various sizes were analysed in each section. Analysis was generally performed at an accelerating potential of 30 $\mathrm{KV}$ and for 100 seconds. To detect oxygen, a 
Table 1 Clinical details of cases studied

\begin{tabular}{|c|c|c|c|c|c|}
\hline $\begin{array}{l}\text { Case } \\
\text { No }\end{array}$ & Age & Initial operation (cement used) & $\begin{array}{l}\text { Interval to revi- } \\
\text { sion }\end{array}$ & Site of biopsy & $\begin{array}{l}\text { Elements on micro- } \\
\text { analysis }\end{array}$ \\
\hline $\begin{array}{l}1 \\
2\end{array}$ & $\begin{array}{l}41 \\
64\end{array}$ & Titanium ring prosthesis & & $\begin{array}{l}\text { Hip joint } \\
\text { Capsule of hip }\end{array}$ & $\begin{array}{l}\mathrm{ZrTi} \\
\mathrm{ZrTi}\end{array}$ \\
\hline 3 & 88 & THR Zimmer D & 4 years & $\begin{array}{l}\text { Darkly stained periarticular fibrous } \\
\text { tissue. Revision of loose hip } \\
\text { prosthesis }\end{array}$ & $\mathrm{ZrTi}$ \\
\hline 4 & 69 & TKR Uncemented PCA & 3 years & $\begin{array}{l}\text { Mass in knee (stiff \& painful) } \\
\text { Fragment of cement from joint }\end{array}$ & $\mathrm{Zr}$ \\
\hline $\begin{array}{l}5 \\
6 \\
7\end{array}$ & $\begin{array}{l}61 \\
52 \\
63\end{array}$ & $\begin{array}{l}\text { TKR Stanmore } \\
\text { Hemiarthroplasty (Palacos) } \\
\text { THR Charnley. Revised after } 1 \\
\text { year }\end{array}$ & $\begin{array}{l}9 \text { years } \\
2 \text { years } \\
13 \text { years }\end{array}$ & $\begin{array}{l}\text { Symovium of knee at revision } \\
\text { Synovium at Girdlestone excision } \\
\text { Interface membrane (loose prosthesis) } \\
\text { at Girdlestone excision arthroplasty }\end{array}$ & $\begin{array}{l}\mathrm{Zr} \mathrm{Co} / \mathrm{Cr} \\
\mathrm{Zr} \mathrm{Ti} \mathrm{Co/Cr} \\
\mathrm{Zr} \mathrm{Cr} / \mathrm{Fe} / \mathrm{Ni} \mathrm{Co} / \mathrm{Cr}\end{array}$ \\
\hline $\begin{array}{l}8 \\
9\end{array}$ & $\begin{array}{l}69 \\
69\end{array}$ & $\begin{array}{l}\text { THR Zimmer D } \\
\text { THR twice }\end{array}$ & $\begin{array}{l}9 \text { years } \\
16 \text { years }\end{array}$ & $\begin{array}{l}\text { Hip } \\
\text { Loose prosthesis, Femoral shaft } \\
\text { interface membrane }\end{array}$ & $\begin{array}{l}\mathrm{Zr} \mathrm{Co} / \mathrm{Cr} \\
\mathrm{Zr} \mathrm{Ba} / \mathrm{S}\end{array}$ \\
\hline 10 & 44 & THR Zimmer (CMW) & 5 years & $\begin{array}{l}\text { Biopsy of inflamed synovium and } \\
\text { capsule }\end{array}$ & $\mathrm{Ti} \mathbf{B a} / \mathbf{S}$ \\
\hline 11 & 76 & $\begin{array}{l}\text { TKR twice (Palacos } R \text { in } 2 n d \\
\text { operation) }\end{array}$ & 2 years & Granulation tissue at arthrodesis & $\mathrm{Zr} \mathrm{Co} / \mathrm{Cr} \mathrm{Fe} / \mathrm{Ni}$ \\
\hline 12 & 76 & THR & & $\begin{array}{l}\text { Membrane from acetabulum at } \\
\text { revision }\end{array}$ & $\mathrm{Zr}$ \\
\hline 13 & 38 & $\begin{array}{l}\text { Irradiated lymphoma. } \\
\text { Pathological fracture neck of } \\
\text { femur Dynamic hip screw }\end{array}$ & & $\begin{array}{l}\text { Articular capsule at revision to total } \\
\text { hip replacement }\end{array}$ & $\mathrm{Cr} / \mathrm{Fe} / \mathrm{Ni}$ \\
\hline $\begin{array}{l}14 \\
15 \\
16\end{array}$ & $\begin{array}{l}57 \\
87\end{array}$ & THR Ultralock (Palacos R) & & $\begin{array}{l}\text { Tissue from hip capsule } \\
\text { Synovium and intramedullary lining }\end{array}$ & $\begin{array}{l}\mathrm{Zr} \mathrm{Ti} \\
\mathrm{Co} / \mathrm{Cr} \mathrm{Cr} / \mathrm{Fe} / \mathrm{Ni}\end{array}$ \\
\hline $\begin{array}{l}16 \\
17\end{array}$ & 76 & $\begin{array}{l}\text { Attenborough TKR (Simplex) } \\
\text { THR }\end{array}$ & 10 years & Tissue from around painful prosthesis & $\mathrm{Co} / \mathrm{Cr}$ \\
\hline 18 & 64 & THR & 18 months & $\begin{array}{l}\text { Inflamed granulation tissue around } \\
\text { painful ?infected joint }\end{array}$ & $\mathrm{Ba} / \mathrm{S}$ \\
\hline $\begin{array}{l}19 \\
20 \\
21\end{array}$ & $\begin{array}{l}73 \\
32 \\
55\end{array}$ & $\begin{array}{l}\text { THR Ultralock (Palacos R) } \\
\text { THR } \\
\text { THR Zimmer D then } \\
\text { Stanmore; (Palacos) }\end{array}$ & $\begin{array}{l}4 \text { years } \\
7 \text { years } \\
7 \text { years }\end{array}$ & $\begin{array}{l}\text { Synovium of hip } \\
\text { Synovium of hip at revision } \\
\text { Synovium and capsule. Revision of } \\
\text { loose prosthesis }\end{array}$ & $\begin{array}{l}\mathrm{ZrTi} \\
\mathrm{Zr} \\
\mathrm{ZrTi} \mathrm{Ba} / \mathrm{S}\end{array}$ \\
\hline $\begin{array}{l}22 \\
23\end{array}$ & $\begin{array}{l}64 \\
82\end{array}$ & $\begin{array}{l}\text { TKR PCA (Simplex) } \\
\text { TKR Attenborough }\end{array}$ & 2 years & $\begin{array}{l}\text { Synovium } \\
\text { Synovium of knee at revision to } \\
\text { cemented Tricon THR }\end{array}$ & $\begin{array}{l}\mathrm{Co} / \mathrm{Cr} \mathrm{Ba} / \mathrm{S} \\
\mathrm{Co} / \mathrm{Cr}\end{array}$ \\
\hline
\end{tabular}

TKR $=$ Total knee replacement. $T H R=$ Total hip replacement.

much lower potential was used, to obtain optimal overvoltage, the ratio between the accelerating potential in the column and the energy of the emitted $x$ rays. Oxygen is near the lower atomic number limit for detection in our EDS system, and minimal column contamination affects our ability to detect it.

Samples of three different named brands of cement were also examined. These are shown in table 2. The cement powder was sprinkled on a slide in each case and mounted in DPX. Double sided tape was used to attach samples of the powder to a Perspex substrate for SEM and EDS.

Bulk samples of used cement removed during prosthesis revision as well as fragments cut from a polyethylene acetabular cup were examined by SEM and EDS.

Correlation was made between the appearances of the human tissue samples and the unused cement samples by light, polarisation and electron microscopy, and EDS findings.

An attempt was made to detect putative contaminating radioactivity in the zirconium containing cement. A full packet $(40 \mathrm{~g})$ of Palacos bone cement containing $6.0 \mathrm{~g}$ of zirconium dioxide was counted for 50000 seconds ( 14 hours) in a large volume counter, using a sodium iodide detector housed in a shielded container and connected to a multichannel analyser.

Table 2 Different brands of cement examined

\begin{tabular}{lll}
\hline Trade name & Manufacturer & $\begin{array}{l}\text { Elements on } \\
\text { microanalysis }\end{array}$ \\
\hline Palacos LV-40 & Kulzer \& Co & $\mathrm{Zr} / \mathrm{O}$ \\
CMW 3 Bone Cement & CMW & $\mathrm{Ba} / \mathrm{S}$ \\
Surgical Simplex P & Howmedica & $\mathrm{Ba} / \mathrm{S}$ \\
\hline
\end{tabular}

\section{Results}

The foreign material identified in the sections included polyethylene, polymethylmethacrylate cement, radiographic contrast media and various metal or metal alloy particles. Individual appearances are described below and analytical findings are summarised in table 1 . SEM of paraffin wax sections showed that it was easy to identify correlating morphological features in any particular section and hence to confirm by EDS the elemental composition of much of the foreign material identified by light and polarising microscopy. However, little additional information was obtained by this technique on the elemental composition of the cement or the polyethylene as these are composed exclusively of common organic elements most of which are too light for detection in an EDS system.

Colourless, transparent, strongly birefringent, organic material in rough elongate shards elicited a florid foreign body-type giant cell reaction. Seen in 10 cases, this material, resistant to routine processing, and giving no EDS reading above background, was assumed to be polyethylene or other plastic wear debris from the prostheses. This interpretation was supported by analysis of fragments cut from a prosthetic acetabular cup; these were birefringent and gave no clear EDS signal above background, consistent with polyethylene which is composed only of carbon and hydrogen.

Polymethylmethacrylate cement was largely dissolved out by routine processing, but the spaces left were identifiable by the admixture of zirconium dioxide particles or barium sulphate. These spaces were usually ovoid, often septate, and of the order of $0.2 \mathrm{~mm}-2 \mathrm{~mm}$ in 
Figure 1 Zirconium dioxide particles in cement space. (A) Light microscopy (haematoxylin and eosin); (B) polarised light (haematoxylin and eosin); (C) low power scanning electron micrograph of paraffin wax section (backscattered electron image); (D) high power secondary electron image.
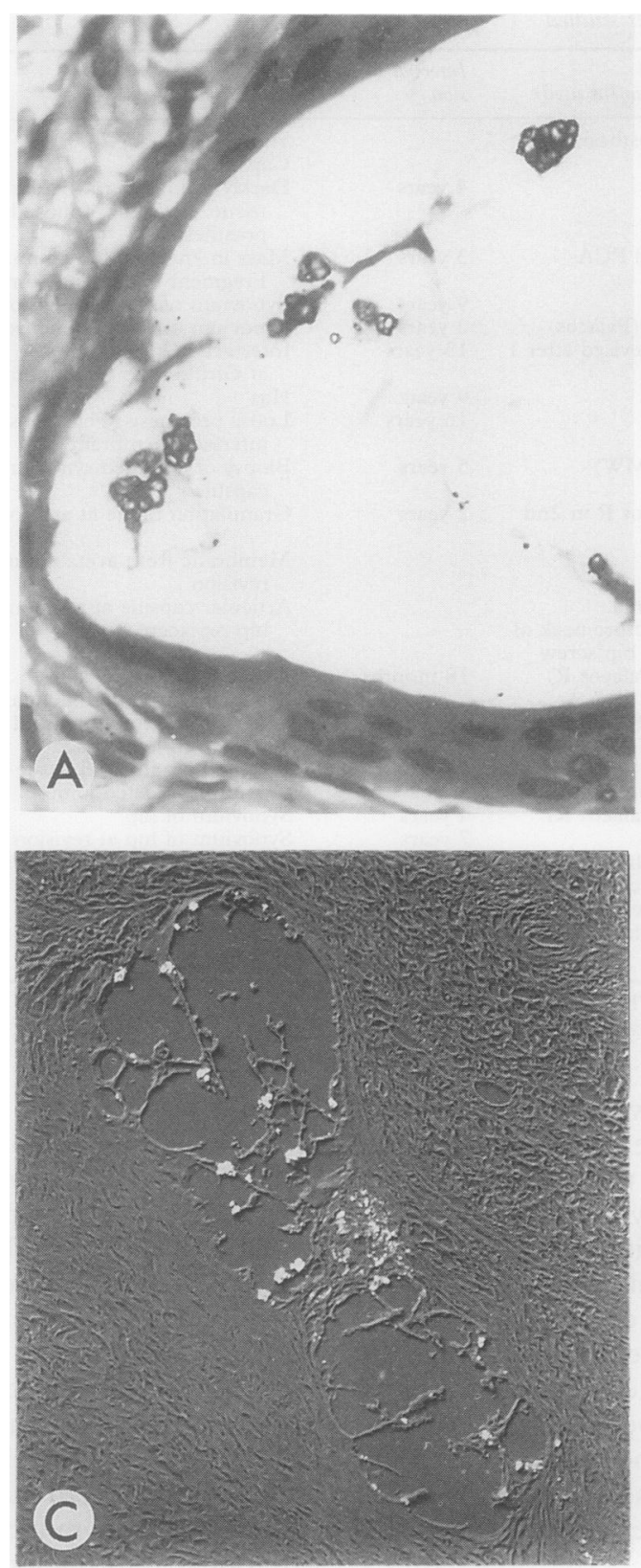

maximum diameter. All but three of the cases included had recognisable cement spaces. The spaces were surrounded by attenuated giant cells, and in all but one case (case 23), contained particles of contrast material. Where it was not completely dissolved away the cement appeared as transparent refractile shards without birefringence. Again analysis of these shards showed no qualitative difference from the perspex substrate. Analysis of the polymethylmethacrylate portion of the bulk cement fragments gave a significant peak for oxygen, again consistent with its elemental composition-namely carbon, oxygen, and hydrogen.

The zirconium dioxide particles (16 cases) consisted of globular aggregates $5-50 \mu \mathrm{m}$ in diameter (fig 1). At low power these appeared dark, but at high power there was some transparency in the centre of the globules. On polarisation the particles exhibited a characteristic "flat" whitish or pale lilac birefringence. Occasionally there was a more discrete partic-
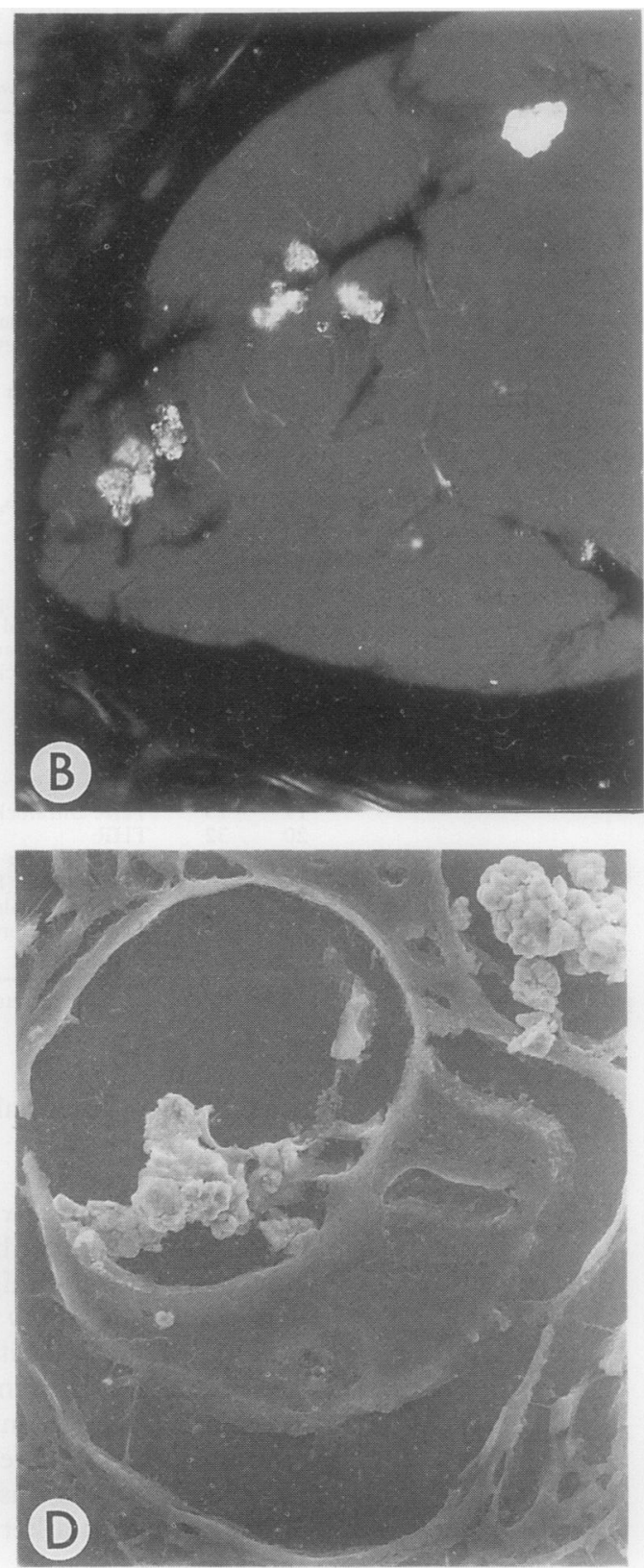

ulate birefringence within the aggregates. In one case the zirconium had a more finely divided granular appearance that was more difficult to distinguish from barium sulphate. However, in this case the granular material was darker than barium and was birefringent like zirconium dioxide.

Microanalysis of all these particles showed that the overwhelming signal was of zirconium but trace amounts of hafnium were also present, (fig 2A). Under optimal circumstances, oxygen, consistent with zirconium dioxide, could also be detected (fig $2 B$ ).

In most cases zirconium could be detected in the cytoplasm of histiocytes away from the cement spaces, (fig 3). This was confirmed by light microscopy and polarisation in seven cases; small particles typical of zirconium dioxide were present in mononuclear phagocytes, often along with metal shards.

Barium sulphate (five cases) (fig 4) was found in similar polymethylmethacrylate cement spaces with surrounding attenuated 
(A)

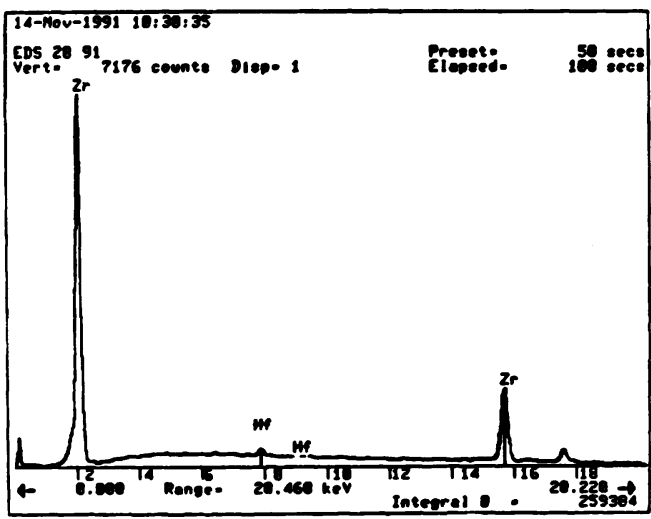

(B)

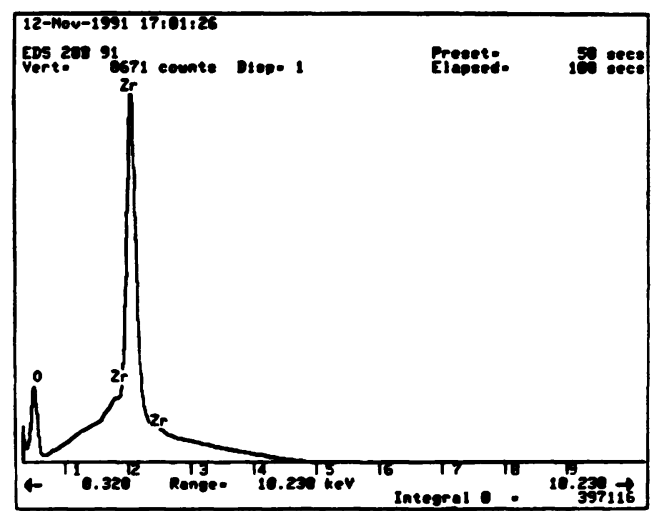

(C)

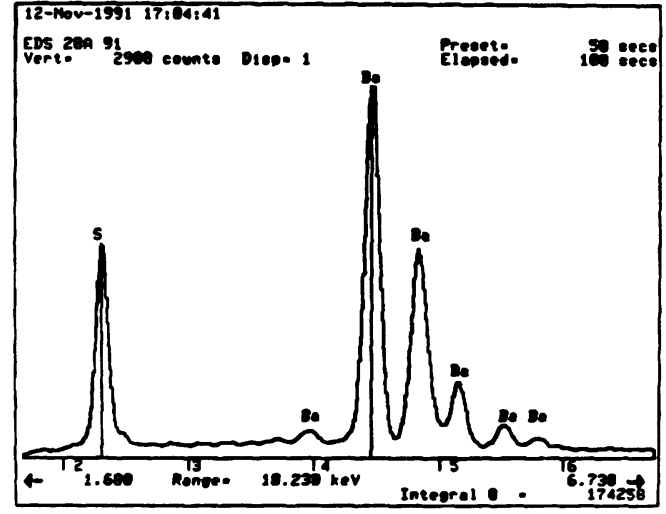

Figure 2 Spectra obtained on microanalysis. $(A)$ Zirconium dioxide analysed at $20 \mathrm{KV}$. Note small peaks for hafnium. (B) Oxygen is shown at $10 \mathrm{KV}$ in the zirconium compound. (C) Barium sulphate.

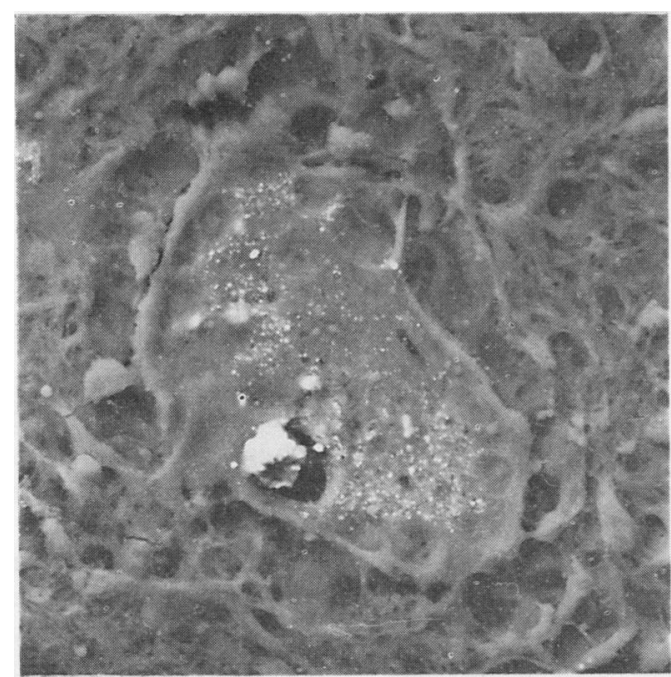

Figure 3 Zirconium dioxide in a macrophage (backscattered electron image). Both the larger particle and the finer granules give a clear zirconium signal on microanalysis. giant cells, but was often very inconspicuous. Sparse collections of particles each about $5 \mu \mathrm{m}$ in diameter were found, and in some cases they had only a very weak hint of the golden-brown hue typical of the barium sulphate usually seen in the intestine. There was a little birefringence on polarisation, but the best method of highlighting the presence of barium was to lower the microscope condenser lens, revealing strong refractility. Clear peaks for barium and sulphur were obtained by EDS of this material (fig 2C).

In the three cases that contained both zirconium dioxide and barium sulphate these contrast media were found in separate cement spaces, never mixed. Zirconium dioxide and barium sulphate were confined to the cases showing cement spaces, confirming their association with cement. In only one case were cement spaces identified without finding zirconium dioxide or barium sulphate, confirming the very widespread use of cement with added contrast media. This case was one of those from which bulk fragments of cement were obtained, and it was confirmed by analysis of these that the cement in this case contained no contrast medium. In all cases where it was known what cement was originally used, the findings on microanalysis were consistent.

Three sorts of metal deposits were noted by EDS and the appearances of these deposits were reviewed by light microscopy. Titanium (nine cases) was finely divided in fairly uniform small black shards in the cytoplasm of sheets of mononuclear, and sometimes multinucleate, vacuolated macrophages. Titanium was often associated with minor aluminium and vanadium signals, expected in titanium alloys. Cobalt/chromium alloy (eight cases) appeared similar, with indistinguishable tissue reaction, but also a tendency to an admixture of larger shards up to $50 \mu \mathrm{m}$ in diameter, often extracellular. Four cases contained particles consisting of chromium/iron/nickel (stainless steel) and in at least one case (case 13) these were deposited without macrophage reaction. All of these metals or alloys gave a similar pattern on polarisation, with a weak pinkish linear glint at the edge of many particles. Four cases showed the presence of two types of metal. Both the cobalt/chrome alloy and the stainless steel gave small EDS peaks for molybdenum, in keeping with the usual composition of these alloys. In practice, we found it impossible to predict reliably the type of metal or alloy from the histological appearance.

The appearances of the contrast media in the unused cement samples (table 2) correlated precisely with those in the human tissues. Light microscopical examination showed that zirconium dioxide was present in globular aggregates identical with those in the cement spaces in the tissues. The barium sulphate was also easily recognisable as such and was much more abundant in the unused cement samples than in the tissue sections. The refractile and polarising properties of the contrast media were also similar to those in the tissues. In all of the samples the contrast media were admixed with transparent, refractile but non- 

sulphate particles in cement space. (A) Polarised light (haematoxylin and eosin); (B) condenser racked down (haematoxylin and eosin); (C) scanning electron micrograph of paraffin wax section (backscattered electron image).
Figure 4 Barium
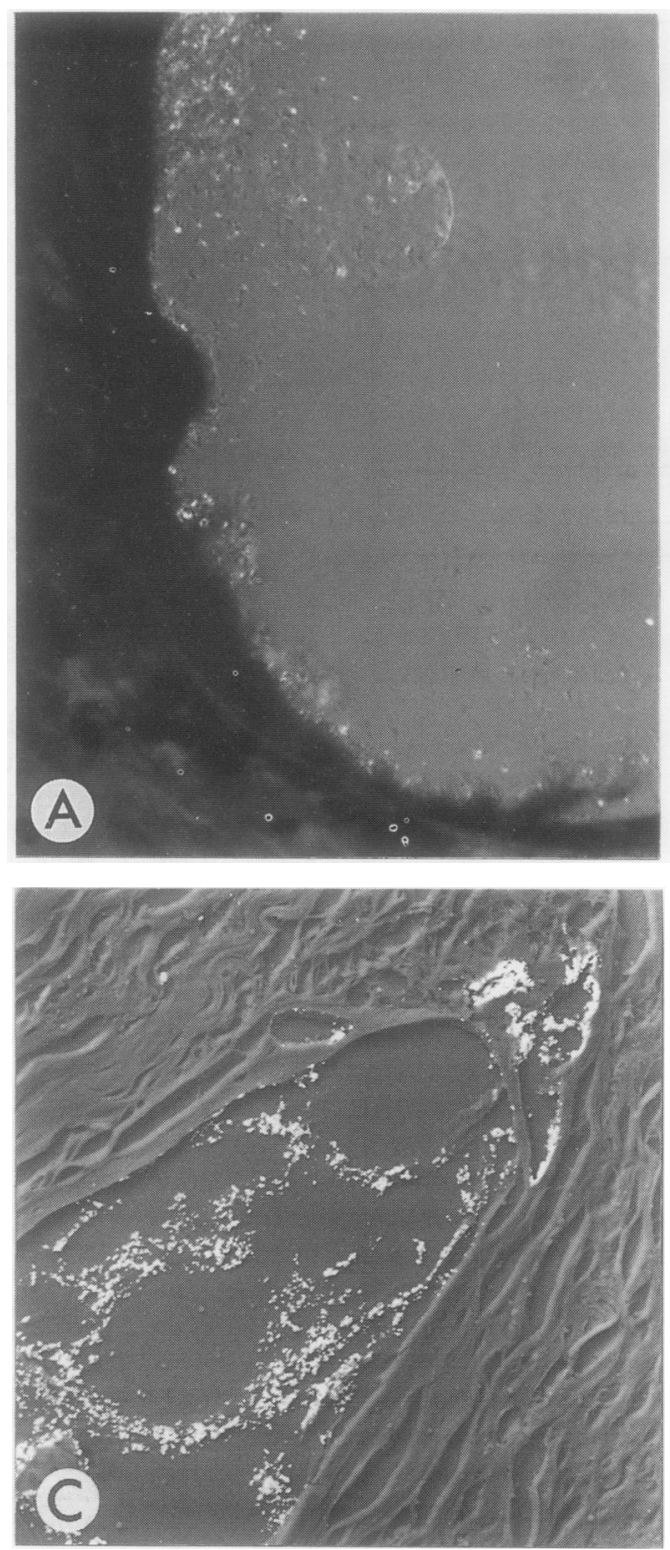

birefringent spheres of polymethylmethacrylate. Scanning electron microscopy showed that there was similar morphological correlation (fig 5) and in the backscatter mode the atomic number contrast highlighted the zirconium dioxide and barium sulphate with respect

Figure 5 Scanning electron micrograph of unused cement sample (Palacos) containing zirconium dioxide particles and showing part of a polymethylmethacrylate cement sphere below.

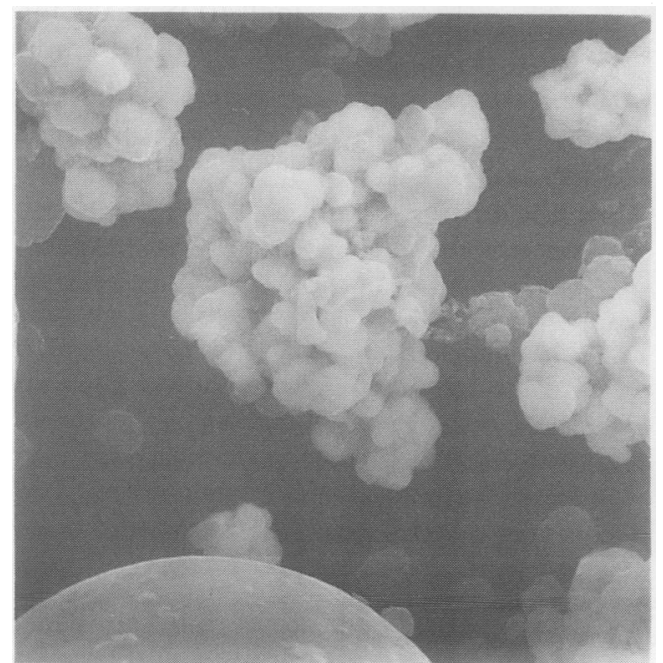

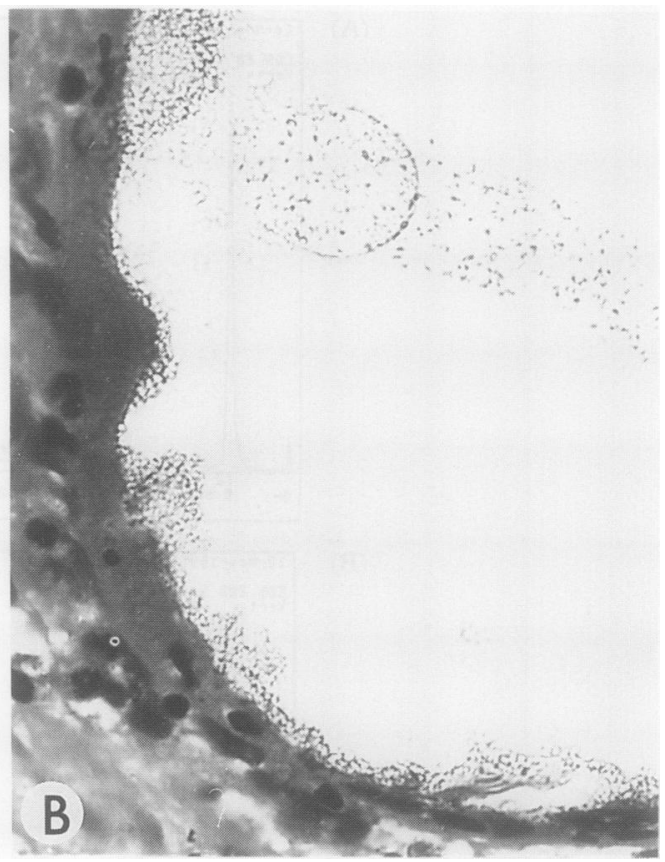

to the organic polymethylmethacrylate spheres and the Perspex substrate. The elements found by microanalysis (table 2) corresponded to those expected from the product information. Again traces of hafnium were found associated with the zirconium, but neither radium nor actinium were detected. Radioactivity was not detected in the zirconium containing cement by the sensitive method used.

\section{Discussion}

The appearances in histological sections of joint prosthesis wear particles of polyethylene, metal, and polymethylmethacrylate cement have been well documented. ${ }^{29}$ We have added detailed descriptions of the appearances by light and polarisation microscopy of the common radiopaque contrast media mixed with polymethylmethacrylate cements. These media are found in the spaces left by removal of the acrylic cement in processing.

Zirconium dioxide is found as small globular aggregates exhibiting a characteristic "flat" whitish birefringence. The shape and situation (mainly in cement spaces) of zirconium dioxide particles in periprosthetic tissues are characteristic and should permit confident recognition by the histopathologist reporting such specimens. The polarisation properties, while distinctive and providing useful confirmation, are not specific. A very similar "flat" whitish birefringence, sometimes with a pinkish hue in stained sections, is seen in tissue specimens containing titanium dioxide. ${ }^{111}$ Other metallic oxides probably show similar polarisation characteristics by light microscopy.

Barium sulphate granules are often sparse and inconspicuous, and show little birefringence, but are strongly refractile. They, too, are found in cement spaces. The specificity of these observations was confirmed by EDS and good morphological correlation was obtained between the light and scanning electron micro- 
scopic appearances.

The occurrence of both media in two cases (9 and 21) in separate cement spaces suggested the use of different cements either at one or more operations, rather than one cement containing a mixture of contrast media. Indeed, each of these patients was found on clinical review to have had three hip replacement operations, although the details of the cement used on every occasion were not available.

We did not find specific tissue reaction patterns for the different contrast media. The tissue reaction to the cement whether it contained barium sulphate, zirconium dioxide, or no contrast medium was the same. We were able to show the presence of zirconium in many cases in the cytoplasm of histiocytes as described by Bos et al. ${ }^{4}$ We are, however, unwilling to speculate on any possible pathogenetic role that these contrast media may have.

On first detecting zirconium in tissues, it took detailed enquiry to discover its source. The fact that barium sulphate or zirconium dioxide is added to bone cement seems not to be widely known by general histopathologists or orthopaedic surgeons. We feel it is worthwhile drawing attention to this fact so that the appearances reported may be recognised more easily. Other sources of zirconium in tissues around prostheses may include second generation zirconia ceramics. ${ }^{12}$ It is also possible that zirconium or its compounds may be found in other types of specimens. For example, it has been used in some dental media, as well as (in the past) for radiographic contrast of the alimentary tract (Zirconotrast which contained zirconium dioxide ${ }^{13}$ ). Hence zirconium might be expected to be found in oral biopsy specimens and in the gastrointestinal tract. Zirconium dioxide and other zirconium salts, such as sodium zirconium lactate and zirconium oxychloride, have been used in deodorant preparations and are said to have caused allergic granulomatous reactions, ${ }^{14}$ but we have no information about the appearances of such compounds in the skin. Despite this we are confident that such particles could be shown to contain zirconium by EDS in a system such as ours.

We were unable to detect radioactivity in the zirconium containing cement sample that we tested. Such radioactivity, due to contamination of natural zirconium by radium and actinium, was reported by Hopf et al. ${ }^{1516}$ They emphasised that only barium sulphate or highly purified zirconium dioxide free of these contaminating radioactive elements should be used in bone cements for human implantation. The levels of radioactivity they detected in zirconium containing cements were very low, but they could not exclude a risk of cumulative damage. It seems unlikely that the rare cases of sarcoma associated with plastic or metal implants $^{17-19}$ could have been related to endogenous radioactivity of the implant or contrast medium in bone cement. It is also interesting that we were able to detect hafnium, a common non-radioactive contaminant of natural zirconium ores. The manufacturers of Palacos are currently seeking alternative sources of zirconium dioxide with sufficiently low residual radiation and without adverse effect on the mechanical properties (Sheard J; Schering-Plough Ltd, personal communication).

We conclude that the diagnostic pathologist, armed with our descriptions, will easily be able to recognise zirconium dioxide and barium sulphate in tissue samples such as ours. As this material becomes more widely recognised, further meaningful pathological studies into the implications of its use may be feasible.

We thank Sarah Allen, senior physicist in the Department of Nuclear Medicine, Guy's Hospita 1, for performing the radioactivity studies on the samples of cement.

1 Willert H-G, Ludwig J, Semlitsch M. Reaction of bone to methacrylate after hip arthroplasty. A long-term gross, light microscopic, and scanning electron microscopic study. $\mathcal{F}$ Bone foint Surg 1974;56-A:1368-82.

2 Revell PA. Tissue reactions to joint prostheses and and the products of wear and corrosion. In: Berry $\mathrm{CL}$, ed. Bone and joint disease. Current topics in pathology 17. Berlin: Springer, 1982:73-10

3 Meachim G, Brooke G. The synovial response to intraarticular acrylic cement particles in guinea pigs. Biomaterials 1984;5:69-74.

4 Bos I, Lindner B, Seydel U, et al. Untersuchungen über die Lockerungsursache bei zementierten Hüftgelenkendoprothesen. Licht- und elektronenmikroskopische Unterprothesen. Licht- und elektronenmikroskopische Untersuchung und Laser-Mik

5 Bos I, Johannisson $R$ Löhrs $U$, Lindner B, Seydel $U$. Comparative investigations of regional lymph nodes and pseudocapsules after implantation of joint endoprospseudocapsules after implantation of

6 Rudigier J, Reck R, Walde H-J, Degreif J. Der Einfluß von Röntgenkontrastmitteln in Knochenzementen auf Bindegewebe und Knochenstruktur. Aktuel Probl Chir Orthop 1987;31:181-3.

7 Isaac GH, Atkinson JR, Dowson D, Kennedy PD, Smith MR. The causes of femoral head roughening in explanted Charnley hip prostheses. Engineering in Medicine 1987;16:167-73.

8 Caravia L, Dowson D, Fisher J, Jobbins B. The influence of bone and bone cement debris on counterface roughness in sliding wear tests of ultra-high molecular weight polyethylene on stainless steel. Proceedings of the Institute of polyethylene on stainless steel. Proceedings

9 Revell PA. The synovial biopsy. In: Anthony PP, MacSween RNM, eds. Recent advances in histopathology Vol 13. RNM, eds. Recent advances in histopathology

10 Morgan CA, Mullick FG, Ishak KG, Johnson FB, Huminer WB. Identification of titanium in human tissues: Probable role in pathologic processes. Hum Pathol 1991;22 450-4.

11 Coelho Filho JC, Moreira RA, Crocker PR, Levison DA Corrin B. Identification of titanium pigment in drug addicts' tissues. Histopathology 1991;19:190-2.

12 Christel PS. Zirconia: The second generation of ceramics for total hip replacement. Bulletin of the Hospital for foin Diseases Orthopaedic Institute 1989;49:170-7.

13 Dalheimer AR, Kaul A, Said MD. Analysis of tissue samples containing colloidal thorium dioxide (Thorotrast) or zirconium dioxide (Zirconotrast): Radiochemical prepzirconium dioxide (Zirconotrast): Radiochemical prep-
aration and alpha-spectrometry. Sci Total Environ aration and alp
1988;70:335-53.

14 Reynolds JEF, ed. Martindale. The extra pharmacopoeia. 29th edn. London: The Pharmaceutical Press, 1989:937.

15 Hopf W, Hopf CG, Glöbel B. About radioactivity in some PMMA bone cements. Acta Orthop Belg 1990;56:443-4

16 Hopf T, Scherr O, Glöbel B, Hopf C. Vergleichende tierexperimentelle Untersuching zur Gewebsverträglichkeit und Messungen der Radioaktivität verschiedene Röntgenkontrastmittel. Z Orthop 1989;127:620-4.

17 Enzinger FM, Weiss SW. Soft tissue tumours. 2nd ed. St. Louis: CV Mosby, 1988:2.

18 Calandruccio RA. Arthroplasty of hip. In: Crenshaw AH, ed. Campbell's operative orthopaedics. 7th edn. St Louis: CV Mosby, 1987:1236.

19 Wapner KL. Implications of metallic corrosion in total knee arthroplasty. Clin Orthop Rel Res 1991;271:12-20. 